\title{
The effect of tobacco Hawkmoth caterpillar extract (Manduca sexta) on the growth and stress resistance of young animals
}

\author{
Nina Khudyakova*, Evgeniy Uschakov, Eva Belial, Liubov Antonova \\ Udmurt State University, Izhevsk, Russia
}

\begin{abstract}
Article deals with the problem of reducing the level of stress and improving the growth and development of young animals during weaning from a nursing female. For this purpose, it is proposed to use an extract of larvae of tobacco hawkmoth (Manduca sexta), containing ecdysone and juvenile hormone. We studied the anxiety of animals in the experimental setup of the light-dark test. Authors conclude that the extract of tobacco hawk moth caterpillars reduces the anxiety of animals. This is manifested by an increase in the latency of entering the dark compartment of the light-dark dough, an increase in the time spent in the light compartment and a decrease in the number of boluses of the litter. It is possible to explain the large increase in body weight of experimental animals in comparison with the animals of the control group by reducing the level of stress and the anabolic effect of caterpillar extract.
\end{abstract}

\section{Introduction}

The young cattle experiences stress when weaning from a nursing mother. The growth and development parameters of both agricultural and laboratory animals deteriorate during this period of life and dietary supplements can mitigate stress effects. Live or frozen tobacco hawk moth caterpillars are the preferred food for exotic animals and pets with various dietary errors and sicknesses. In this form, caterpillars are expensive and therefore inaccessible feed. By extracting biologically active substances, it is possible to concentrate and stabilize them in the extract. Tobacco caterpillars contain enough ecdysone and juvenile hormone for extraction [1]. The purpose of this study was to establish the effect of tobacco hawk moth caterpillar extract on the growth and stress resistance of young cattle.

\section{Methodology}

\subsection{Caterpillar cultivation}

\footnotetext{
* Corresponding author: whitemouse@udm.ru
} 
Manduca sexta caterpillars were kept in hatcheries and fed up on artificial feed produced by "ExoLife" up to age 3-4. Further, the caterpillars were frozen at $-18^{\circ} \mathrm{C}$ and stored in this state (no more than 1 month) until the preparation of the extract.

\subsection{Preparation of tobacco hawk moth caterpillar extract}

The extract of tobacco hawk moth (HM) caterpillars was prepared on $40 \%$ ethyl alcohol solution based on the equivalent amount of alcohol solution per weight of caterpillars. For every $50 \mathrm{ml}$ of crushed frozen caterpillars, $50 \mathrm{ml}$ of $40 \%$ ethanol solution was added and drawn for 3-5 days. The extract was not drained from the sediment. Supernatant fluid was added to the animal feed. The concentration of ethyl alcohol in resulting HM caterpillars extract was $15.2 \%$.

\subsection{Feed preparation for mice}

Oat flakes were used to prepare feed for mice, which were boiled in water at a rate of $25 \mathrm{~g}$ of flakes per $50 \mathrm{~g}$ of water until soft and formed thick porridge. The finished porridge was added with $0.1 \mathrm{ml}$ Manduca sexta feed extract for every $20 \mathrm{~g}$ of feed for animals of the experimental group or $0.1 \mathrm{ml} 15.2 \%$ ethanol solution for every $20 \mathrm{~g}$ of feed for control.

\subsection{Feeding animals}

The feed mixture was laid out in feeders at the rate of $20 \mathrm{~g}$ per animal. The water in the cage was unrestricted. Animals were kept in standard home cells at $12 \mathrm{~h}$ day/night cycle under the conditions of Udmurt State University vivarium.

\subsection{Animals}

The work is done on 60 young adult white mice aged 21 and 28 days. The young animals were withdrawn from lactating mothers at the age of 21 days, which is the standard procedure at a given age. Two equal groups of young cattle were formed, one of which received an extract of tobacco hawk moth caterpillars, the other $-15.2 \%$ ethyl alcohol with feed. Before the experiment began and after one week of feeding the abovementioned feed, animals were weighed and tested in the conditions of a black-and-white chamber.

\subsection{Testing in a black-and-white chamber}

A black-and-white chamber (BWC) test was used to investigate animal behavior. The BWC unit produced by "Open science" was a standard $32 * 30 * 60 \mathrm{~cm}$ chamber divided into 2 compartments with a floor area of $30 * 30 \mathrm{~cm}$. The black compartment had a cover and was completely blackout. A $40 \mathrm{~W}$ filament lamp was installed above the light compartment at a height of $1 \mathrm{~m}$ from the floor. Black and white compartments were divided by a partition. The partition had a hole for the animal's free passage from the light compartment to dark and back. The animal was set down in a light compartment facing the wall opposite to the opening. The following behavior parameters were recorded: latent period (LP) of entering the dark compartment (s), the residence time in the light and dark compartment (s), the number of passages from one chamber to another and the number of litter boles. Testing time in BWC was 5 minutes. 30 minutes before testing began, a home cage with animals was installed near an experimental unit for animals' adaptation. 


\subsection{Processing of results}

Based on the results of behavior parameters, the average value and average value error were calculated in the Statistics 8.0 program. The validity of the results was assessed on the nonparametric Mann-Whitney and Wilcoxon criteria.

\section{Results and discussion}

\subsection{Results}

Before the experiment began and after it, the animals were weighed. Body weight of control and experimental groups' animals had no reliable difference (table 1)

Table 1. Body weight of experimental and control groups' animals.

\begin{tabular}{|l|c|c|c|}
\hline & Control & Experiment & $\begin{array}{l}\text { Reliability of } \\
\text { control- } \\
\text { experiment } \\
\text { differences }\end{array}$ \\
\hline $\begin{array}{l}\text { weight before } \\
\text { experiment, g }\end{array}$ & $9.2 \pm 0.9$ & $9.1 \pm 0.8$ & - \\
\hline $\begin{array}{l}\text { Weight in a } \\
\text { week, g } \text { a }\end{array}$ & $11.2 \pm 1.0$ & $14.4 \pm 0.7$ & $\mathrm{p}<0.05$ \\
\hline $\begin{array}{l}\text { Reliability of } \\
\text { differences } \\
\text { within the group }\end{array}$ & - & $\mathrm{p}<0.05$ & \\
\hline
\end{tabular}

Eating oatmeal is a rather scarce diet compared to standard rodent feed, so no reliable increase in body weight of control group's animals was observed. The experimental group showed a reliable $(\mathrm{p}<0.05)$ increase in animal weight from $9.1 \pm 0.5 \mathrm{~g}$ to $14.4 \pm 0.4 \mathrm{~g}$. There were also reliable weight differences between the animals of the control group and the experimental group at the end of the experiment (table 1).

Table 2. Latent period of the first entry into the dark BWC compartment of animals of the experimental and control group.

\begin{tabular}{|l|c|c|c|}
\hline & Control & Experiment & $\begin{array}{l}\text { Reliability of } \\
\text { control- } \\
\text { experiment } \\
\text { differences }\end{array}$ \\
\hline $\begin{array}{l}\text { LP before the } \\
\text { experiment, s }\end{array}$ & $13.3 \pm 1.5$ & $11.5 \pm 2.2$ & - \\
\hline LP in a week, s & $10.2 \pm 0.8$ & $59.2 \pm 20.0$ & $\mathrm{p}<0.001$ \\
\hline $\begin{array}{l}\text { Reliability of } \\
\text { differences within } \\
\text { the group }\end{array}$ & - & $\mathrm{p}<0.007$ & \\
\hline
\end{tabular}

At the beginning of the experiment for mice of the experimental group, the time of entering the dark BWC compartment was $11.5 \pm 2.17 \mathrm{~s}$. After a week of using water-alcohol HM larvae extract, the latent period of the first entry of experimental group's mice reliably $(p<0,007)$ increased relative to initial values of this group and amounted to $59.2 \pm 20.0 \mathrm{~s}$, indicating a decrease in the anxiety of this group's animals.

In mice of the control group, LP of the first entry at the beginning of the experiment was $13.3 \pm 1.5 \mathrm{~s}$. After a week of porridge feed, this parameter amounted to $10.2 \pm 0.8 \mathrm{~s}$. No 
significant change in this parameter was noted in mice of the control group relative to the initial values. Thus, after a week's consumption of food containing water-alcohol HM larvae extract, LP of the first entry into the dark BWC compartment in experimental group's animals was reliably $(\mathrm{p}<0,001)$ different from such in the control group (table 2$)$

Table 3. Time of mice presence in the dark BWC compartment of experimental and control groups' animals

\begin{tabular}{|l|c|c|c|}
\hline & Control & Experiment & $\begin{array}{l}\text { Reliability } \\
\text { control- } \\
\text { experiment } \\
\text { differences }\end{array}$ \\
\hline $\begin{array}{l}\text { Time before the } \\
\text { experiment, s }\end{array}$ & $243.8 \pm 5.9$ & $247.4 \pm 4.9$ & - \\
\hline Time in a week, s & $243.5 \pm 7.4$ & $191.9 \pm 21.7$ & $\mathrm{p}<0.001$ \\
\hline $\begin{array}{l}\text { Reliability of } \\
\text { differences } \\
\text { within the group }\end{array}$ & - & $\mathrm{p}<0.02$ & \\
\hline
\end{tabular}

At the beginning of the experiment, experimental group's mice presence in the dark chamber was $243,5 \pm 4.9$ s. After a week of water-alcohol HM larvae extract usage, the average presence of experimental group's mice in the dark chamber was $191.9 \pm 21.7 \mathrm{~s}$. Data obtained during the experiment on two of these dependent samples when receiving wateralcohol HM larvae extract were reliable $(p<0,02)$, which indicates anxiety decrease in this group's animals. Animals of the experimental group really spent less time in the dark BWC compartment.

In the control group's mice at the beginning of the experiment, the average time in the dark chamber was $243.8 \pm 5.9 \mathrm{~s}$. After a week of porridge feed without HM extract, the average presence in the dark chamber did not significantly change and amounted to $247,4 \pm$ $7.4 \mathrm{~s}$.

Thus, the control and experimental groups did not initially differ in the parameter of staying time in the dark BWC compartment and acquired reliable differences at the end of the experiment, since the differences obtained in the experiment on these two independent samples are reliable $(\mathrm{p}<0.01)$, (table 3$)$.

Table 4. Time of mice presence in the light BWC compartment of experimental and control groups' animals

\begin{tabular}{|l|l|l|l|}
\hline & Control & Experiment & $\begin{array}{l}\text { Reliability of } \\
\text { control-experiment } \\
\text { differences }\end{array}$ \\
\hline $\begin{array}{l}\text { Time before the } \\
\text { experiment, s }\end{array}$ & $56.2 \pm 5.9$ & $56.5 \pm 4.9$ & - \\
\hline Time in a week, s & $52.6 \pm 7.4$ & $108.1 \pm 21.7$ & $\mathrm{p}<0.001$ \\
\hline $\begin{array}{l}\text { Reliability of } \\
\text { differences within } \\
\text { the group }\end{array}$ & - & $\mathrm{p}<0.02$ & \\
\hline
\end{tabular}

Since the total time of each animal's stay in the BWC was 5 minutes $(300 \mathrm{~s})$, the results for animal's stay in the light chamber's compartment are related to the previous parameter. For experimental group's mice at the beginning of the experiment before receiving HM larvae extract, the average experimental group's stay time in the light part of the chamber was $56.5 \pm 4.9 \mathrm{~s}$. After a week of water-alcohol HM larvae extract application, the average time of experimental group's mice stay in the light chamber compartment increased to $108.1 \pm 21.7 \mathrm{~s}$, which indicates a decrease in this group's animals' anxiety. The data obtained 
during the experiment on two of these dependent samples when receiving water-alcohol HM larvae extract are reliable $(\mathrm{p}<0,02)$.

At the beginning of the experiment, the average time of control group's mice in the light chamber's compartment was $56.2 \pm 5.9 \mathrm{~s}$. After a week of porridge application, the average time in this part of the chamber practically did not change and amounted to $52,6 \pm 7.4 \mathrm{~s}$.

Thus, the control and experimental groups did not initially differ in the parameter of time in the light BWC compartment and acquired reliable differences at the end of the experiment, since the differences obtained in an experiment on these two independent samples are reliable $(\mathrm{p}<0.01)$, (table 4$)$.

Table 5. The number of exits from the dark to the light compartment of the control and experimental groups' animals.

\begin{tabular}{|l|c|c|c|}
\hline & Control & Experiment & $\begin{array}{c}\text { Reliability of control- } \\
\text { experiment differences }\end{array}$ \\
\hline $\begin{array}{l}\text { Parameter before } \\
\text { the experiment, pcs }\end{array}$ & $8.8 \pm 0.7$ & $9.1 \pm 0.9$ & - \\
\hline $\begin{array}{l}\text { Parameter in a } \\
\text { week, pcs }\end{array}$ & $10.7 \pm 0.9$ & $8.3 \pm 1.05$ & \\
\hline $\begin{array}{l}\text { Reliability of } \\
\text { differences within } \\
\text { the group }\end{array}$ & - & - & \\
\hline
\end{tabular}

At the beginning of the experiment before receiving water-alcohol HM larvae extract, the average number of experimental group's mice exits from the dark to the light chamber was $9.1 \pm 0.9$. After a week of water-alcohol HM larvae extract application, the average number of exits from dark to light chamber of experimental group's mice was $8.3 \pm 1.1$. In control group's mice before the experiment, the average number of exits from the dark to the light chamber was $8.8 \pm 0.7$. In control group's mice after a week of porridge consumption without HM extract, the average number of exits from dark to light chamber amounted to $10.7 \pm 0.9$. No reliable differences between groups and within the group for this parameter were observed (table 5).

Table 6. Quantity of defecations in animals of control and experimental groups.

\begin{tabular}{|l|c|c|c|}
\hline & Control & Experiment & $\begin{array}{c}\text { Reliability of control- } \\
\text { experiment differences }\end{array}$ \\
\hline $\begin{array}{l}\text { Parameter before the } \\
\text { experiment, pcs }\end{array}$ & $1.6 \pm 0.2$ & $1.7 \pm 0.3$ & - \\
\hline $\begin{array}{l}\text { Parameter in a week, } \\
\text { pcs }\end{array}$ & $1.1 \pm 0.3$ & $0.5 \pm 0.1$ & $\mathrm{p}<0.01$ \\
\hline $\begin{array}{l}\text { Reliability of } \\
\text { differences within the } \\
\text { group }\end{array}$ & - & $\mathrm{p}<0.01$ & \\
\hline
\end{tabular}

At the beginning of the experiment before receiving alcohol HM larvae extract, the average number of defecations of experimental group's mice was $1.7 \pm 0.3$. After a week of water-alcohol HM larvae extract application, the average number of defecations of experimental group's mice reliably decreased $(\mathrm{p}<0,01)$ and amounted to $0,5 \pm 0,1$. In control group's mice at the beginning of the experiment, the number of defecations was $1,6 \pm 0.2$; after a week of porridge consumption, the average number of defecations was $1,1 \pm 0.3$.

The data obtained from the experiment show that the differences between the control and the experimental groups are reliable $(p<0.01)$, (table 6). Anxiety decreases only in animals of the experimental group. 


\subsection{Results and Discussion}

For this study, the tobacco hawk moth caterpillars were used precisely 3-4 of age, because ecdysone accumulates in its body when the caterpillar grows and the pupal stage approaches. Ecdyzone causes the onset of the insect's molting and its transition into the next phase of development. The onset of the next stage is slowed down by juvenile hormone. Juvenile hormone causes the retention of larval traits by activating "larval" genes and suppressing the imago cuticle formation genes and metamorphosis. With the increasing age of the caterpillar, the content of the juvenile hormone in its body decreases. At 3-4 age, the HM caterpillar still has enough juvenile hormone and already enough ecdysone. When preparing water-alcohol extract it was considered that ecdysone has a larger number of alcohol groups than cholesterol, soluble in water and alcohol, is a polar molecule. By chemical nature, juvenile hormone is a derivative of terpenes, which are poorly soluble in water and well soluble in alcohol. Thus, ecdysteroids and juvenile hormone can move into a water-alcohol mixture when preparing HM caterpillar extract.

Young animals were chosen for the present study because the weaning period is particularly stressful for both agricultural and laboratory animals. During this period, animals slow down in growth, the productivity and survival of young animals decrease. The presence of biologically active additives to the diet allows to mitigate the animal's transition to independent life, ensure its best growth and development. Ecdysteroids have an anabolic effect comparable to prohibited anabolic agents [2,3] such as methandienone, but they are safe and readily available in the form of phyto- or zooecdysteroids. Therefore, for this study, HM caterpillar ecdysteroids were chosen as these caterpillars are widely used in veterinary for nursing and feeding exotic and domestic animals and stimulating effect of such feed is known. Thus, in this study, a HM caterpillar extract containing ecdysone and juvenile hormone was applied.

When combined with ecdysone, juvenile hormone enhances receptor-dependent ecdysone transcription and increases protein synthesis [1] potentiating the anabolic effect. The anabolic effect of both hormones may explain the reliable $(\mathrm{p}<0.05)$ increase in body weight of experimental group's animals found in this study compared to the control (table 1). Ecdysone does increase muscle size and muscle fiber diameter [3]. With the direct action of the isolated 20-hydroxyecdysone injected intraperitoneally, the anabolic effect was much worse than when exposed to a "cocktail" of natural ecdysteroids derived from biological objects [4,5]. Ecdysteroids act in low doses comparable to those used in this study. When administered orally, they retain efficiency comparable to intraperitoneal administration. Thus, increased muscle mass, increased protein synthesis and inhibition of its catabolism makes ecdysteroid extracts of natural origin promising preparations to be used in veterinary practice.

As for the reduction in the anxiety level observed in this study, the following points can be noted. The black and white chamber is a recognized model test for the study of animal anxiety. In these experiments, the anxiety reduction of experimental group's animals was noted by such behavior parameters as the first dark compartment entry LP, stay in the light/dark chamber compartment and defecation. Reliable increase in LP of the first entry into the dark BWC compartment from $11.5 \pm 2.2 \mathrm{~s}$ to $59.2 \pm 20,0 \mathrm{~s}(\mathrm{p}<0.007)$ (table 2), an increase in animal's stay time in the light BWC compartment by almost 2 times (from $56.5 \pm 4.9 \mathrm{~s}$ to $108.1 \pm 21.7 \mathrm{~s}$ (table4)) and reduced time in the dark compartment (from $247.4 \pm 4.9 \mathrm{~s}$ to $191.9 \pm 21.7 \mathrm{~s}(\mathrm{p}<0.02)$ (table 3$)$ ), decrease in defecation from $1.7 \pm 0.3$ to $0.5 \pm 0.1(\mathrm{p}<0.01)($ table 6$)$ - all this is undoubtedly a consequence of reducing anxiety level of animals which consumed water-alcohol HM caterpillar extract with food during the first weeks of weaning from the mother. The decrease in the anxiety level observed in this study can be explained by ecdysteroids induction of glutamate decarboxylase synthesis [6] in 
brain tissues, a decrease in the amount of acetylcholinesterase [7] and the resulting neuroprotective action of ecdysone [5].

In addition to the modulating action of "pure" ecdysone on the GABA receptor and the cholinergic mediator system, it is possible that when isolated from biological objects, ecdysteroids mixture contains additional specific metabolites. Some authors [8,9] link decreased anxiety level to change in expression of phosphatidylinositol-3- kinase and protein kinase $\mathrm{B}$ genes in mammalian brain cells responsible for antiapoptotic effect.

Thus, ecdysteroids contained in the extract of tobacco hawk moth caterpillars can have significant antidepressant and anxiolytic effects manifested in reducing the anxiety of young animals in its weaning from the mother, as well as the anabolic effect.

\section{Conclusion}

The use of water-alcohol extract of tobacco hawk moth larvae during young animals' weaning from the mother showed a reliable $(p<0.05)$ decrease in the level of animal anxiety, which is confirmed by statistical data of increasing the latent period time of the first entry into the dark compartment, the time of staying in the light section of the blackand-white chamber, the decrease in the time of mice staying in the dark compartment of the black-and-white camera, reducing the number of defecation acts. Reducing the stress of young animals and the anabolic effect of the used extract of the tobacco mock caterpillars can explain reliably $(\mathrm{p}<0.05)$ large increase in body weight of experimental animals compared to control.

\section{References}

1. V.C. Henrich, E. Burns, D.P. Yelverton, E. Christensen, C Weinberger, Insect Biochem Mol Biol. 33(12), 1239-47 (2003) doi: 10.1016/j.ibmb.2003.08.002.

2. E. Isenmann, G. Ambrosio, J.F. Joseph, M. Mazzarino, X .de la Torre, P. Zimmer, R. Kazlauskas, C. Goebel, F. Botrè, P. Diel, M.K. Parr, Arch Toxicol, 93(7), 1807-1816 (2019) doi: 10.1007/s00204-019-02490-X

3. M.K. Parr, F.Botrè, A.Naß, J. Hengevoss, P. Diel, G. Wolber. BiolSport, 32(2), 169-73 (2015) doi: 10.5604/20831862.1144420.

4. S. Kumpun, J.P. Girault, L. Dinan, C.Blais, A.Maria, C. Dauphin-Villemant, B. Yingyongnarongkul, A. Suksamrarn, R .Lafont. J Steroid, Biochem Mol Biol., 126 (12), 1-9 (2011) doi: 10.1016/j.jsbmb.2011.03.016.

5. L. Dinan, R. Lafont. J. Endocrinol, 191(1), 1-8 (2006) doi: 10.1677/joe.1.06900

6. K.D. Chaudhary, P.J. Lupien, C. Hinse, Experientia, 25, 250-251 (1969)

7. R.E. Catalan, M.D. Aragones, J.E. Godoy, A.M. Martinez, Comparative Biochemistry and Physiology, 78, 193-19 (1984)

8. S. Constantino, R. Santo, S. Gisselbrecht, F. Gouilleux, EuropeanCytokine Network 12, 365-367 (2001)

9. I. Oehme, S. Bosser, M. Zornig, Cell Death and Differentiation, 13, 189-201 (2006) 